\title{
Geociênciacias
}

\section{Evolution of arc magmatism in the Carmópolis de Minas Layered Suite, Minas Gerais, Brazil: Sm-Nd and Rb-Sr isotope geochemistry}

\section{Evolução do magmatismo de arco na Suíte Acamadada Carmópolis de Minas, Minas Gerais, Brasil: geoquímica isotópica Sm-Nd e Rb-Sr}

Luís Emanoel Alexandre Goulart

Programa de Pós-graduação em

Evolução Crustal e Recursos Naturais,

Departamento de Geologia,

Escola de Minas, UFOP, Brasil.

alexandregoulart@degeo.ufop.br

\section{Mauricio Antonio Carneiro}

Instituto Federal de Ensino

Tecnológico de Minas Gerais, Araxá

mauricio_araxa@hotmail.com

\section{Resumo}

A Suíte Acamadada Carmópolis de Minas (SACM) é uma unidade neoarqueana, metamorfisada em condições de fácies anfibolito a granulito, composta por rochas metaultramáficas, anfibolitos e metarriolitos. A SACM é marcada por duas fases distintas de magmatismo tholeítico e calcio-alcalino. A geologia regional e suas características litogeoquímicas apontam a SACM como suíte arco-tholeiítica metamorfizada, do tipo boninito-basalto-andesito-riolito, interpretada como um remanescente de arco oceânico juvenil desmembrado. As rochas de afinidade tholeiítica apresentam assinatura de manto empobrecido a enriquecido, com $\varepsilon_{\mathrm{Nd}(t)}$ positivo a fracamente negativo e $\varepsilon_{\text {Sr(t) }}$ predominantemente positivo, indicando assimilação crustal. As rochas de afinidade cálcio-alcalina apresentam assinatura de crosta juvenil com $\varepsilon_{\mathrm{Nd}(t)}$ próximos ao CHUR e $\varepsilon_{\mathrm{Sr}(\mathrm{t})}$ fracamente positivo. A idade isocrônica $(\mathrm{Sm}-\mathrm{Nd})$ de $2736 \pm 300 \mathrm{Ma}$, obtida com $\varepsilon_{\mathrm{Nd}(\mathrm{i})}=+0,4$, sugere a edificação de um arco intraoceânico durante as etapas tardias do Evento Tectonotermal Rio das Velhas. A evolução do arco envolveu magmatismo tholeiítico nos estágios iniciais em associação de magmatismo cálcio-alcalino, de caráter provavelmente anatético, nos estágios tardi-orogênicos.

Palavras-chave: Isótopos de $\mathrm{Nd}$ e Sr, magmatismo de arco, Complexo Metamórfico Campo Belo.

\footnotetext{
Abstract

The Carmópolis de Minas Layered Suite (CMLS) is a Neoarchean Unit metamorphosed at amphibolite- to granulite-facies conditions, comprised of metaultramafic rocks, amphibolites and metarhyolites. The CMLS is marked by two distinct phases of tholeiitic and calc-alkaline magmatism. Previous geochemical data and regional constraints suggest that the CMLS is possibly a metamorphosed arctholeiitic suite of the type boninite-basalt-andesite-rhyolite, interpreted in this study as a dismembered remnant of the juvenile oceanic arc. The rocks of tholeitic affinity record a signature of depleted to enriched mantle with positive to weakly negative $\varepsilon_{N d(t)}$
} 
and predominantly positive $\varepsilon_{\text {Sr(t) values }}$ indicating some degree of crustal assimilation. The rocks of calc-alkaline affinity present a signature of juvenile crust with $\varepsilon_{\mathrm{Nd}(t)}$ close to the CHUR and weakly positive $\varepsilon_{S r(t)}$ values. The Sm-Nd isochron age of $2736 \pm$ $300 \mathrm{Ma}$ obtained with $\varepsilon_{\mathrm{Nd}(i)}=+0.4$, suggests the edification of an intra-oceanic arc during the late phases of the Rio das Velhas Tectonothermal Event. The arc evolution involved tholeiitic magmatism in the early stages in association with calc-alkaline magmatism, of probably anatectic character, in the tardy-orogenic stages.

Keywords: Nd and Sr isotopes, arc magmatism, Campo Belo Metamorphic Complex.

\section{Introduction}

The Archean crust in the Southern São Francisco Craton (SSFC), records a polyphase evolution dating back to the formation of one of the first continental nuclei in South America at about 3.2 Ga (Teixeira et al. 1998; Machado \& Carneiro 1992; Machado et al. 1992; Romano et al. 2013; Lana et al. 2013). Early studies by Teixeira et al. (1996; 1998), indicate that an acrescionary event at circa 3.0-2.9 Ga amalgamated several crustal segments that currently constitute the TTG metamorphic complexes in the surroundings of the Quadrilátero Ferrífero mining district. This event may have involved formation and consumption of oceanic floor, as indicated by the presence of Archaean komatiitic-tholeiitic sequences (Machado \& Schrank 1989, Pimentel \& Ferreira Filho 2002), cropping out to the west of the Campo Belo Metamorphic Complex (CBMC), in a tectonic window of the basement, in the domain of the Brasilia Belt. The late stages of this great event of crustal thickening culminated in an episode of high-grade metamorphism and regional migmatization dated between 2.86 and $2.84 \mathrm{Ga}$ (Teixeira et al. 1996 and 2000). Subsequently, these crustal segments were reworked during the evolution of the Rio das Velhas (RV) Tectonothermal Event (Machado \& Carneiro 1992). The RV Tectonothermal Event was related to the installation of an active continental

\section{Regional geology and location}

The Carmópolis de Minas Layered Suite (CMLS) crops out in the southern portion of the São Francisco Craton, in the Campo Belo Metamorphic Complex (Figure 1). The CMLS comprises an association of Archaean metamorphosed lithotypes similar to modern suites of boninite-basalt-andesite-rhyolite type. The unit presents itself folded, forming a synformal structure, with a $20 \mathrm{~km}$ long, NE-SW trending axis, eroded during tectonic denudation that exposed the margin in the domains of Southern São Francisco Craton at ca. 2.78 Ma (Carneiro 1992; Machado \& Carneiro 1992; Teixeira et al. 1998). In metamorphic complexes of the Quadrilátero Ferrífero, the climax of this event is recorded by episodes of granitogenesis correlated to a crustal relaxation phase, resulting from orogenic collapse, represented by the granites Mamona (Machado et al. 1989), Santa Luzia (Noce et al. 1998) and Brumadinho (Carneiro 1992). Recent LA-ICP-MS work by Romano et al (2013) and Lana et al. (2013) have provided a large number of $\mathrm{U}-\mathrm{Pb}$ zircon ages that confirm previous studies by Carneiro (1992), Teixeira et al. (1998) and Machado \& Carneiro (1992). According to these authors the TTG rocks were emplaced during tree main magmatic phases, referred to as the Santa Bárbara (3220-3200 Ma), Rio das Velhas I (RV I; 2930-2900 Ma) and Rio das Velhas II (RV II; 2800-2770 Ma) events. The Carmópolis de Minas Layered Suite corresponds to a segment of a dismembered juvenile magmatic arc, with minimum age of $\approx 2713 \mathrm{Ma}$ (Goulart \& Carneiro 2010, Goulart et al. 2013a), located in Campo Belo Metamorphic Complex. This episode of arc magmatism was active between the late stages of RV Event and the emplacement of potassic granitoids in the crust (Lana et al. 2013, Romano et al. 2013). Regional constraints and geochemical

basement do SSFC. The regional sialic substrate of the CMLS comprises TTG gneisses known as Claudio and Fernão Dias Gneisses (Carneiro et al. 2006) that compose the Campo Belo Metamorphic Complex. Contacts between the CMLS and these gneisses are inferred. The observed regional deformation and preliminary ages (Goulart \& Carneiro 2010) suggest that CMLS was accreted to Archean crustal segments (e.g. Gneiss Claudio and Gneiss Fernão Dias - Carneiro et al. 2006), data (Goulart et al. 2013b unpublished) suggest that this suite has evolved from the primitive mantle sources for juvenile crustal sources as a consequence of several petrogenetic and tectonic processes correlated to the evolution of this arc. However, currently available data about the contribution of these sources in Campo Belo Metamorphic Complex is still scarce. Some indications of juvenile components in rocks of this region were obtained through of $\mathrm{Pb}-\mathrm{Pb}, \mathrm{Sm}-\mathrm{Nd}$ and $\mathrm{Rb}-\mathrm{Sr}$ isotope in gneisses (Teixeira et al. 1996, 1998), komatiites (Pimentel \& Ferreira Filho 2002) and intraplate mafic-ultramafic intrusions (Carneiro et al. 2004). This paper presents $\mathrm{Sr}$ and $\mathrm{Nd}$ isotopic results of metarhyolites, amphibolites and metaultramafic rocks from the CMLS that characterize this Unit as an Achaean juvenile arc-related magmatic suite. The results presented here contribute to the understanding of a still little known period of arc magmatic activity that occurred during the building of the Campo Belo Metamorphic Complex. At the same time, corroborate the interpretation of several authors (Machado and Carneiro 1992, Teixeira et al., 2000, Lana et al. 2013) of which juvenile magmatic processes, accretion and crustal recycling were preponderant for the building of the sialic basement in the ambit of the SSFC.

during a compressive phase of the Rio das Velhas Tectonothermal Event (Carneiro 1992), and closure of oceanic basins that now comprise the several greenstone sequences present in the region (e.g. Rio das Velhas greenstone belt). Locally the sedimentary remnants of these basins are represented by thin lenses of iron formations. Sometimes these bodies are interspersed with lenses and layers of quartzite and garnet-amphibolite totally granulitized as observed in the vicinity 
of CMLS (this work). Intruded into this stratigraphic sequence, are granitoids and

\section{General characteristics of CMLS}

Although the lithotypes of CMLS record their original mineralogy in large part modified by metamorphism, with evident recrystallization in high amphibolite to granulite facies conditions, one tholeiitic and other calc-alkaline magmatic phase were differentiated.

Among the studied rocks metaperidotites, metapyroxenites, hornblendites, amphibolites, leuco-amphibolites, and intermediate to acidic rocks were de-

\section{Materials and methods}

Isotopic ratios of the $\mathrm{Sm}-\mathrm{Nd}$ and $\mathrm{Rb}$-Sr systems in eleven samples of the lithological framework that compose CMLS were quantified. Massive and layered units were sampled. The selected samples for analyses did not present younger hydrothermal or intemperic alterations. They were also free of accessory minerals such as garnet, allanite and monazite. The samples were prepared (crushing and pulverizing)

\section{Results}

Samples were collected in the northern limit of the CMLS, in the region of closure of the Carmópolis de Minas Syncline (Figure 1). The mafic and ultramafic domains are relatively well defined in this area. Occasionally, felsic injections intrude parallel or subparallel the metaultramaficamphibolitic layering. The analyzed samples include two metaperidotites (samples LRDU-2 and LRDU-3), one metawebsterite (sample LREU-6), four amphibolites (samples AP-3, AP-4, LA-1 and LA-23), three leuco-amphibolites (samples MA-1, MA-2 and LA-7) and one metarhyolite (MR-1). The Sm-Nd and Rb-Sr isotope analyses are displayed in Tables 1 and 2 .

The samples MR-1 and MA-1 (respectively leuco-amphibolite and metarhyolite) were collected at the same sampling site (UTM: 540888/7733485). The rocks crop out in the Paiol river bed that is exposed during the dry seasons. The exposed beds show NE-SW-vertical to subvertical layering. The metarhyolite occurs as beds or felsic injections that were emplaced parallel to subparallel to the primary layering. It commonly contains amphibolite enclaves, mafic microgranu- three mafic dyke systems (two NW-SE and one NE-SW), designated as Lençóis

I, Lençóis II and Timboré (Carneiro et al. 2006). scribed, being these last interpreted as meta-andesites and metarhyolites. The chemical composition of these lithotypes indicates that their protoliths comprised a classical arc-tholeiitic suite of the boniniteandesite-basalt-rhyolite type (Goulart et al. 2013b unpublished).

Some leuco-amphibolites present at the contact between amphibolite and metarhyolite, exhibit relictic poikilitic crystals of hornblende and pyroxene, microgranular aggregates and mafic enclaves, suggesting relictic structures of the "magma mingling" type. One phase of low grade metamorphism or hydrothermal activity is also recorded in this unit. It corresponds to veins of several generations, filled with fibrous serpentine in metaultramafic rocks and the veins filled by quartz and carbonate/ feldspar in metamafic and acidic rocks. in the Laboratório de Preparação de Amostras para Geocronologia (LOPAG)/Departamento de Geologia/ Escola de Minas/UFOP. The isotopic data was obtained using a multicollector Finnigan MAT 262 mass spectrometer from the geochronology Laboratory of the University of Brasília (3 samples) and a VG-354 multicollector mass spectrometer at the CPGeo/Instituto de Geociências/USP
(8 samples) (for analytical procedures see Gioia \& Pimentel 2000; Sato et al. 1995). The Sm-Nd TDM model ages were calculated according to DePaolo (1981 and 1988). The isotope ratios and "epsilon" parameters were calculated to $\mathrm{T}=2713 \mathrm{Ma}$ that is the minimum age of the CMLS (Goulart \& Carneiro 2010; Goulart et al., 2013a). The isochron age was calculated in the Isoplot 3.0/ Ex (Ludwig, 2001). lar aggregates and poikilitic crystals of hornblende and pyroxene, suggesting processes of assimilation or magma mingling.

At the contact between amphibolite and metarhyolite, a distinctive low-grade mineral assemblage, comprised of albitic feldspar- fibrous actinolite-chlorite-epidote occurs. Scapolite-bearing amphibolites were observed in stratified outcrops exposed a few kilometers to the east, in the same domain of the CMLS. The metarhyolite MR-1 is fine-grained with a granoblastic to lepidogranoblastic and nematogranoblastic texture, consisting of a granoblastic matrix with albitic plagioclase, K-feldspar and quartz, where subordinate levels of brown biotite and/or pyroxenes occur. Zircon is relatively abundant in this sample. The analysis yielded low ${ }^{147} \mathrm{Sm} /{ }^{144} \mathrm{Nd}$ ratio $(\approx 0.1034)$ and $\mathrm{f}_{\mathrm{Sm} / \mathrm{Nd}}$ value $(\approx-0.4743)$, compatible with acidic rocks (Faure 1988), allowing that it was calculated TDM age model of $2860 \mathrm{Ma}$. The ${ }^{143} \mathrm{Nd} /{ }^{144} \mathrm{Nd}{ }_{(\mathrm{t})}$ ratios $(0.50912)$ and $\varepsilon \mathrm{Nd}_{(2713)}$ values $(-0.25)$ equate to CHUR are consistent with enriched mantle sources or crustal juvenile sources. The ${ }^{87} \mathrm{Sr}^{/ 86} \mathrm{Sr}_{(2713)}$ ratios $(\approx 0.70215)$ and $\varepsilon \mathrm{Sr}_{(2713)}$ values $(+12)$ close to the UR corroborate the $\mathrm{Nd}$-isotope results and point a crustal juvenile sources in the magma genesis of the CMLS. Sample MA-1 (leuco-amphibolite) was obtained from a plagioclase-rich lens in amphibolitic bed. This sample exhibited a thin granoblastic texture, composed of partially recrystallized plagioclase intercalated with subordinate quantities of pyroxene, partially replaced by hornblende, suggesting preserved mesocumulate texture.

The analysis yielded low ${ }^{147} \mathrm{Sm} /{ }^{144} \mathrm{Nd}$ ratio $(\approx 0.1698)$, low $\mathrm{f}_{\mathrm{Sm} / \mathrm{Nd}}$ value $(\approx-0.1369)$ and Sm-Nd TDM age model of 3266 Ma. The isotope composition this sample showed low ${ }^{143} \mathrm{Nd} /{ }^{144} \mathrm{Nd}{ }_{(2713)}$ ratio (0.50910) and weakly negative $\varepsilon \mathrm{Nd}_{2713}$ values $(-0.55)$, comparable to enriched mantle sources or juvenile crustal sources. However the extremely high ${ }^{87} \mathrm{Sr}^{86}{ }^{86} \mathrm{r}_{(2713)}$ ratios $(\approx 0.75229)$ and strongly positive $\varepsilon \operatorname{Sr}_{(2713)}$ values $(+725)$ are anomalous. Part of these results may be reflecting the low-grade paragenesis generate by metasomatic alteration between acidic magma and preexistent mafic rock (see Morgan \& London 1987). 


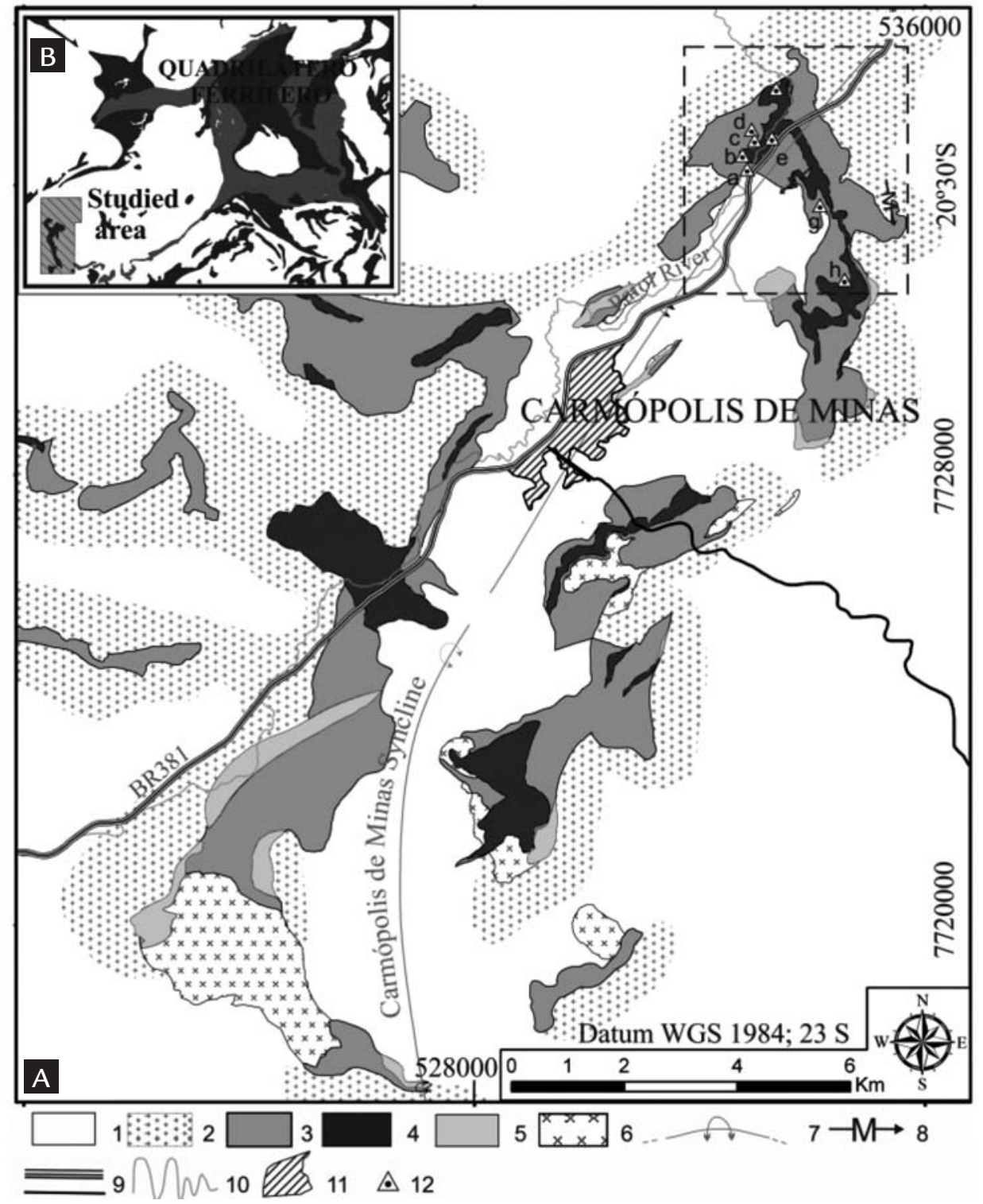

\begin{tabular}{|c|c|c|c|c|c|c|c|c|c|c|}
\hline Rock & Sample & $\mathrm{Sm}$ & Nd & ${ }^{147} \mathrm{Sm} /{ }^{144} \mathrm{Nd}$ & ${ }^{143} \mathrm{Nd} /{ }^{144} \mathrm{Nd}$ & $\left|{ }^{143} \mathrm{Nd} /{ }^{144} \mathrm{Nd}{ }_{(2713)}\right|$ & $E(0)$ & $\mathrm{ENd}_{2713} \mid$ & $\mathbf{f}_{\mathrm{Sm} / \mathrm{Nd}}$ & $\begin{array}{l}\text { TDM } \\
(\mathrm{Ma})\end{array}$ \\
\hline \multirow[t]{2}{*}{ Metaperidotite } & LRDU-2 & 0.45 & 1.4 & $\begin{array}{c}0.1944 \pm \\
0.009000\end{array}$ & $\begin{array}{l}0.51303 \pm \\
0.000015\end{array}$ & 0.51012 & 7.59 & 8.39 & -0.01 & - \\
\hline & LRDU-3 & 0.60 & 1.80 & $\begin{array}{c}0.2016 \pm \\
0.011200\end{array}$ & $\begin{array}{l}0.51340 \pm \\
0.000011\end{array}$ & 0.50980 & 14.82 & 13.14 & 0.0247 & - \\
\hline Metawebsterite & LREU-6 & 0.32 & 1.30 & $\begin{array}{c}0.1488 \pm \\
0.008300\end{array}$ & $\begin{array}{l}0.51181 \pm \\
0.000011\end{array}$ & 0.50915 & -16.15 & 0.41 & -0.2433 & 2945 \\
\hline \multirow{4}{*}{ Amphibolite } & AP-4 & 2.42 & 11.40 & $\begin{array}{c}0.1284 \pm \\
0.007100\end{array}$ & $\begin{array}{l}0.51209 \pm \\
0.000008\end{array}$ & 0.50979 & -10.75 & 12.90 & -0.3474 & - \\
\hline & AP-3 & 1.30 & 4.10 & $\begin{array}{c}0.1917 \pm \\
0.010600\end{array}$ & $\begin{array}{l}0.51242 \pm \\
0.000007\end{array}$ & 0.50898 & -4.36 & -2.64 & -0.0253 & - \\
\hline & $A E-1$ & 3.90 & 13.00 & $\begin{array}{c}0.1814 \pm \\
0.010100\end{array}$ & $\begin{array}{l}0.51243 \pm \\
0.000009\end{array}$ & 0.50945 & -4.05 & 1.24 & -0.08 & 2985 \\
\hline & AE-23 & 1.13 & 3.70 & $\begin{array}{c}0.1847 \pm \\
0.0102500\end{array}$ & $\begin{array}{l}0.51277 \pm \\
0.000004\end{array}$ & 0.50946 & 2.48 & 6.64 & -0.0611 & - \\
\hline \multirow{3}{*}{$\begin{array}{l}\text { Leuco- } \\
\text { amphibolite }\end{array}$} & MA-1 & 1.46 & 5.20 & $\begin{array}{c}0.1698 \pm \\
0.009423\end{array}$ & $\begin{array}{l}0.51213 \pm \\
0,000004\end{array}$ & 0.50910 & -9.85 & -0.55 & -0.1369 & 3266 \\
\hline & MA-2 & 2.20 & 7.66 & $\begin{array}{c}0.1736 \pm \\
0.009634\end{array}$ & $\begin{array}{c}0.51227 \pm \\
0.00002\end{array}$ & 0.50916 & -7.16 & 0.84 & -0.1175 & 2980 \\
\hline & LA-7 & 2.69 & 9.08 & $\begin{array}{c}0.1793 \pm \\
0,009949\end{array}$ & $\begin{array}{l}0.51233 \pm \\
0.000012\end{array}$ & 0.50912 & -6.05 & -0.012 & -0.0887 & 3260 \\
\hline Metarhyolite & MR-1 & 7.93 & 46.34 & $\begin{array}{c}0.1034 \pm \\
0.0057\end{array}$ & $\begin{array}{l}0.51097 \pm \\
0.000021\end{array}$ & 0.50912 & -32.54 & -0.25 & -0.4743 & 2860 \\
\hline
\end{tabular}

Figure 1

A) Lithostructural map of the CMLS. Rectangle in the upper right corner shows the sampled area.

B) Simplified geological map of the Quadrilátero Ferrífero pointing the position of the studied area.

Key: 1 and 2 - gneisses of the

Campo Belo Metamorphic Complex;

3 - metamafic rocks;

4 - metaultramafic rocks;

5 - iron formation, metachert;

6 - granitoids;

7 -regional fold axis;

8 - M, Z or S fold axes;

9 - highways;

10 - rivers;

11 - cities;

12 - sampling sites

(a - samples Ma-1 and MR-1;

b - sample LRDU-3;

c- sample AP-4;

d- sample AP-3;

e- sample AE-23;

f- sample LRDU-2;

g- samples AE-1, MA-2 and LA-7;

h- sample LREU-6).
Table 1

Sm-Nd whole-rock results. 


\begin{tabular}{|c|c|c|c|c|}
\hline & Rock & Sample & ${ }^{87} \mathrm{Sr} /{ }^{86} \mathrm{Sr}{ }_{2713}$ & $\mathrm{ESr}_{2713}$ \\
\hline & \multirow{2}{*}{ Metaperidotite } & LRDU-2 & 0.70247 & 13.81 \\
\hline & & LRDU-3 & 0.70153 & 3 \\
\hline & Metawebsterite & LREU-6 & 0.69342 & -112 \\
\hline & \multirow{4}{*}{ Amphibolite } & AP-4 & 0.70108 & -3 \\
\hline & & AP-3 & 0.72099 & 280 \\
\hline & & $A E-1$ & 0.70617 & 69 \\
\hline & & AE-23 & 0.70479 & 49 \\
\hline & \multirow{3}{*}{ Leuco-amphibolite } & MA-1 & 0.75229 & 725 \\
\hline & & MA-2 & 0.70678 & 78 \\
\hline Table 2 & & LA-7 & 0.70558 & 61 \\
\hline $\begin{array}{r}{ }^{87} \mathrm{Sr} /{ }^{86} \mathrm{Sr}_{2713} \text { and } \mathrm{E}_{\mathrm{Sr}(2713)} \\
\text { whole-rock results. }\end{array}$ & Metarhyolite & MR-1 & 0.70215 & 12 \\
\hline
\end{tabular}

The samples LRDU-2 and LRDU-3 (metaperidotites; respectively UTM 7734760/541411 and UTM 7733658/540829) were collected at circa 200 meters from the left bank of the Paiol River, west of the BR381 Highway. These rocks crop out in a relatively banded domain, close to the contact with a mafic layer. The samples exhibit fine- to medium-grained texture and are partially serpentinized. The two samples exhibit a matrix with a granoblastic texture composed of clinopyroxene, orthopyroxene and pseudomorphs of serpentinized olivine. Nematoblastic crystals of tremolite and $\mathrm{Mg}$-hornblende grow at the expense of pyroxenes over the matrix. Sulfides, spinels and magnetite occur in subordinate quantities hosted in pyroxene. The ${ }^{147} \mathrm{Sm} /{ }^{144} \mathrm{Nd}$ ratios are high for metaultramafic rocks and showed values of $\approx 0.1944$ and 0.2016 . The $\mathrm{f}_{\mathrm{Sm} / \mathrm{Nd}}$ parameter showed high values (-0.01 and 0.0247), inconsistent with metamorphosed primitive rocks, originated of mantle-derived protolith (Sato 1998). These samples showed Sm$\mathrm{Nd}$ model ages meaningless. The samples yielded very high ${ }^{143} \mathrm{Nd} /{ }^{144} \mathrm{Nd}$ (t) ratios $(\approx$ 0.50980 and 0.51012$)$ and $\varepsilon \mathrm{Nd}_{2713}^{(t)}$ values $(\approx+8.39$ and +13.14$)$. The samples also showed very positive $\varepsilon \mathrm{Nd}_{(0)}$ values, incompatible with the isotopic evolution of the mantle. This data suggests a possible readjustment in the light rare earth elements contents. The ${ }^{87} \mathrm{Sr} /{ }^{86} \mathrm{Sr}_{(2713)}$ ratios $(\approx$ 0.70153 and 0.70247$)$ and $\varepsilon \operatorname{Sr}_{(2713)}$ values $(\approx+3$ and +13.81$)$ are more positive and/ or higher than the UR. This data suggests crustal assimilation in small proportions.

The samples AP-3 and AP-4 (amphibolites; respectively UTM:541001/7734089 and
$541025 / 7733988$ ) were obtained in two near outcrops situated on a small hill to the left bank of the Paiol River. Sample AP-3 records a granonematoblastic texture composed by nematoblastic hornblende (> 80\% vol.) and subordinately recrystallized plagioclase. Zircon, titanite, apatite, magnetite and ilmenite are the main trace minerals. Sample AP-4 exhibit a granonematoblastic to granoblastic texture composed of plagioclase and nematoblastic hornblende with relictic crystals of pyroxene. Zircon, titanite, magnetite and apatite are rare accessory minerals. The analyses presented low to high ${ }^{147} \mathrm{Sm} /{ }^{144} \mathrm{Nd}$ ratios ( $\approx 0.1284$ and 0.1917). The likewise variable $\mathrm{f}_{\mathrm{Sm} / \mathrm{Nd}}$ parameter values $(-0.3474$ and -0.0253) obtained for these samples indicate important changes in $\mathrm{Nd}$ isotopic composition of these samples. These samples did not record consistent Sm$\mathrm{Nd}$ age models. Sample AP-3 showed low ${ }^{143} \mathrm{Nd} /{ }^{144} \mathrm{Nd}{ }_{(2713)}$ ratio $(\approx 0.50898)$ and negative $\varepsilon \mathrm{Nd}_{(2713)}$ value $(-2.64)$. These values are still within the field of enriched mantle sources, however the highest ${ }^{87} \mathrm{Sr} /{ }^{86} \mathrm{Sr}_{(2713)}$ ratios $(\approx 0.72099)$ and anomalously positive $\varepsilon \operatorname{Sr}_{(2713)}$ values $(+280)$ suggest isotopic disturbance. Sample AP-4 yields a very high ${ }^{143} \mathrm{Nd} /{ }^{144} \mathrm{Nd}{ }_{(2713)}$ ratio $(\approx 0.50979)$ and a strongly positive $\varepsilon \mathrm{Nd}_{(2713)}$ value $(+12.90)$, higher than the expected values for Achaean depleted mantle sources (DePaolo 1988). The value of ${ }^{87} \mathrm{Sr} /{ }^{86} \mathrm{Sr}_{(2713)}$ ratio is low $(\approx 0.70108)$ and $\varepsilon \operatorname{Sr}_{(2713)}$ value is negative $(-3)$, consistently characterizing it as depleted mantle sources.

The amphibolite AE-23 (UTM: 541355/7733929) was sampled near to BR381 Highway. The outcrop pres- ents massive structure and apparent NE-subvertical layering. This rock, exhibiting a granonematoblastic texture defined by nematoblastic hornblende that grew on the matrix, is constituted by stretched granular crystals of recrystallized plagioclase. Rare relictic pyroxene crystals were observed. Zircon, titanite, magnetite, ilmenite and apatite are rare accessory minerals that occur in small amounts. The high ${ }^{143} \mathrm{Nd} /{ }^{144} \mathrm{Nd}{ }_{(2713)}$ ratio $(\approx 0.50946)$ and positive $\varepsilon \mathrm{Nd}_{(2713)}$ value $(+6.64)$. These results suggest a mantelic depleted source, however the analyses also yielded positive $\varepsilon \mathrm{Nd}_{(0)}$, indicating a remobilization in the light rare earth contents. The high ${ }^{87} \mathrm{Sr} /{ }^{86} \mathrm{Sr}_{(2713)}$ ratio $(\approx 0.70479)$ and very positive $\varepsilon S r_{(2713)}$ parameter $(+49)$ indicate significant modifications in the $\mathrm{Sr}$ isotope compositions of the sample. The analyses revealed ${ }^{147} \mathrm{Sm} /{ }^{144} \mathrm{Nd}$ ratio of $\approx 0.1847$ compatible with metamafic rocks (e.g. Sato 1998), but presented high $\mathrm{f}_{\mathrm{Sm} / \mathrm{Nd}}$ parameter value $(\approx-0.0611)$, suggesting isotopic fractionation, not providing a SmNd TDM model of geological significance.

Sample LREU-6 (metawebsterite; UTM: 542629/7731418) were sampled in the eastern limb of the Carmópolis de Minas Synclinal, circa 2000 meters from the BR-381 Highway. The exposed rocks display N-S foliation, parallel or sub-parallel to primary layering, defined by fine- to medium-grained granoblastic texture composed by two-pyroxenes assemblage. We interpret this texture as a relictic adcumulate texture. The analysis revealed relatively low ${ }^{147} \mathrm{Sm} /{ }^{144} \mathrm{Nd}$ ratio $\approx$ $0.1488)$ and $\mathrm{f}_{\mathrm{Sm} / \mathrm{Nd}}$ parameter $(\approx-0.2433)$, yielding Sm-Nd TDM model age of 2945 Ma. The ${ }^{143} \mathrm{Nd} /{ }^{144} \mathrm{Nd}_{(2713)}$ ratio $(\approx 0.50915)$ higher than CHUR and positive $\varepsilon \mathrm{Nd}_{(2713)}$ 
value $(+0.41)$ are consistent with depleted mantle sources. On the other hand, the anomalously low ${ }^{87} \mathrm{Sr} /{ }^{86} \mathrm{Sr}_{(2713)}$ ratio $(\approx$ $0.69342)$ and strongly negative $\varepsilon \operatorname{Sr}_{(2713)}$ value $(\approx-112)$ indicate a probable isotopic disturbance correlated to remobilization of $\mathrm{Rb}-\mathrm{Sr}$ contents.

The samples AE-1 (amphibolite), MA-2 and LA-7 (leuco-amphibolite) were obtained in the single outcrop (UTM: 542132/7732771). This sampling site is located approximately 1200 meters to NW of the previous point, in the eastern limb of the Carmópolis de Minas Syncline. The rocks record NE subvertical relict igneous layering. The layered strata exhibit size graded layers and composition defined by the abundance of plagioclase. Sample AE-1 showed a granonematoblastic to granoblastic texture composed of plagioclase and hornblende with relictic twinned crystals of pyroxene, marginally recrystallized. Prismatic ghost crystals of plagioclase exhibit intense internal recrystallization, generating aggregates of elongated subgrains and new grains. Zircon, titanite, magnetite, ilmenite and

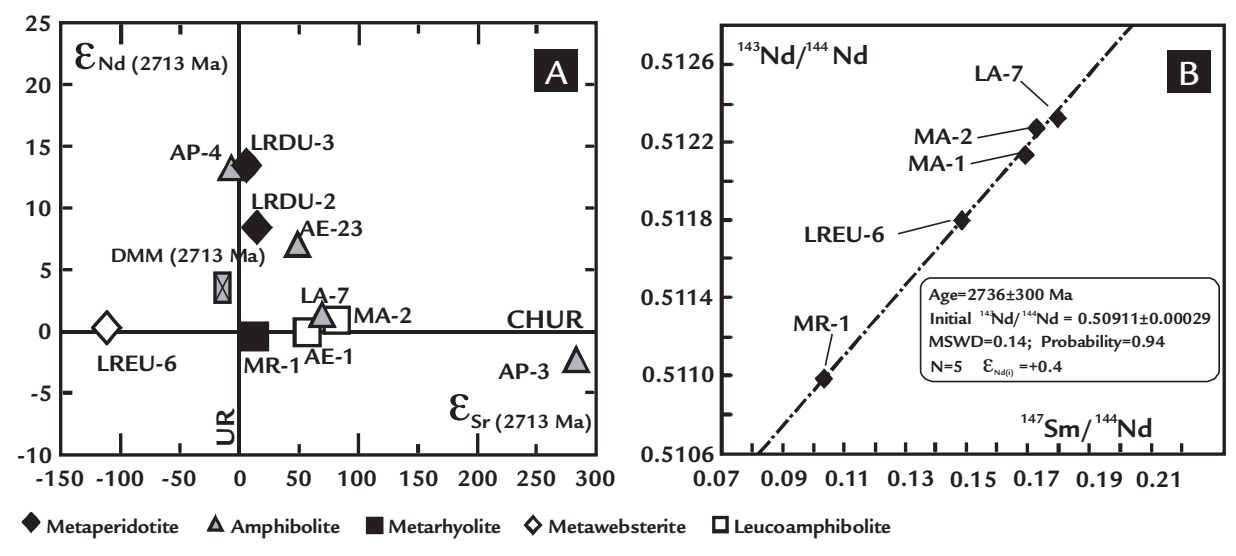

\section{Discussion and conclusions}

The sample set presented in this study represents two magmatic phases. Samples LRDU-2, LRDU-3 LREU-6, PA4, AP-3, EA-1, EA-23, MA-1, MA-2 and LA-7 (metaultramafic rocks, amphibolites and leuco-amphibolites) correspond to the phase of tholeiitic magmatism, precursor of the first evolutive stages of the CMLS. Sample MR-1 (metarhyolite) represents the phase of calc-alkaline magmatism, active during the more evolved stages. The arrangement of analytical points in Figure $2 \mathrm{~A}$ suggests that the original magmas of CMLS evolved from depleted mantle sources $\left(\varepsilon_{\mathrm{Nd}}>0\right.$; e.g. DMM - Depleted Mantle MORB) to enriched mantle sources or juvenile crustal reservoir (weakly apatite are rare or absent accessory minerals. Analysis showed ${ }^{147} \mathrm{Sm} /{ }^{144} \mathrm{Nd}$ ratios $(\approx$ 0.1814) compatible with metamafic rocks, however with high $\mathrm{f}_{\mathrm{Sm} / \mathrm{Nd}}$ parameter value $(\approx-0.08)$, pointing a TDM age model of $2985 \mathrm{Ma}$. The obtained ${ }^{143} \mathrm{Nd} /{ }^{144} \mathrm{Nd}{ }_{(2713)}$ ratio $(0.50945)$ and positive $\varepsilon \mathrm{Nd}_{(2713)}$ value $(+1.24)$ indicate mantelic juvenile sources. High ${ }^{87} \mathrm{Sr}^{86}{ }^{86} \mathrm{Sr}_{(2713)}$ ratio $(\approx 0.70617)$ and strongly positive $\varepsilon S r_{(2713)}(+69)$ indicate remobilization of $\mathrm{Sr}$, probably during metamorphism or metasomatic processes. The leuco-amphibolites MA-2 and LA-7 exhibit relict cumulatic texture defined by accumulation of poikilitic crystals of hornblende and pyroxenes in adcumulatic matrix constituted by plagioclase. The matrix hosted in poiquilitic crystals presents different composition of the matrix in wich they are imerse, caracterized by the presence of plagioclase and less frequently by Fe-Ti-oxides. These paragenesis and textures suggest interaction between mafic and acidic magmas (see Storey et al. 1989) in the genesis of the CMLS. The analyses yielded low ${ }^{147} \mathrm{Sm} /{ }^{144} \mathrm{Nd}$ ratios $(\approx 0.1736$ 0.1793) compatible with amphibolites.

negative $\varepsilon_{\mathrm{Nd}}$ values). The ${ }^{87} \mathrm{Sr} /{ }^{86} \mathrm{Sr}_{(2713)}$ isotope ratios have predominantly higher values than those of the Uniform Reservoir (UR - Figures 2A) and a frequent positive $\varepsilon_{\mathrm{Sr}(2713)}$, indicating variable assimilation of the crustal components during the magmatic activity of CMLS. In particular, the sample MR-1 (metarhyolite) showed a slightly negative $\varepsilon_{\mathrm{Nd}(2713)}$ value $(-0.25)$ and low ${ }^{143} \mathrm{Nd} /{ }^{144} \mathrm{Nd}{ }_{(2713)}$ ratio $\approx$ $0.50912)$, indicating that the calc-alkaline magmatism was derived from the juvenile crustal reservoir with short crustal residence time, preserving characteristics of the enriched mantle source. The positive $\varepsilon_{\mathrm{Sr}(2713)}$ parameter $(+12)$ and low ${ }^{87} \mathrm{Sr} /{ }^{86} \mathrm{Sr}$ ${ }_{(2713)}$ ratio $(\approx 0.70215)$ corroborate this in-
Figure 2

A) Variation diagram of $\varepsilon_{\mathrm{Nd}(\mathrm{t})} \times \varepsilon_{\mathrm{Sr}(\mathrm{t}) \text {. }}$ B) Sm-Nd isochron diagram with the five whole rock samples that defined the better linear array.

The $\mathrm{f}_{\mathrm{Sm} / \mathrm{Nd}}$ parameter values are high $(\approx$ -0.0887 and -0.1175$)$, but equally consistent with mafic rocks. The samples MA-2 and LA-7 presented respectively $\mathrm{Sm}-\mathrm{Nd}$ TDM age models of 2980 and $3260 \mathrm{Ma}$. The ${ }^{143} \mathrm{Nd} /{ }^{144} \mathrm{Nd}{ }_{(2713)}$ ratio $(\approx 0.50912$ and 0.50916) near of the CHUR values and positive to slightly negative $\varepsilon \mathrm{Nd}_{(2713)}$ value (+0.84 to -0.012 ) indicate contributions of mantelic depleted sources and mantelic enriched sources/crustal juvenile sources in varying proportions. The high ${ }^{87} \mathrm{Sr}^{86}{ }^{86} \mathrm{Sr}_{(2713)}$ ratios $(\approx 0.70558$ and 0.70678$)$ and strongly positive $\varepsilon \mathrm{Sr}_{(2713)}(+61$ and +78$)$ corroborate the contributions of crustal components in the petrogenesis of the CMLS.

The analyses of the samples MR-1, LREU-6, LA-7 and MA-2 MA1, which theoretically exhibit the most preserved $\mathrm{Sm}-\mathrm{Nd}$ isotopic system of the sample set, defined a reasonable adjustment of analytical points, yielding an isochron age of $2736 \pm 300 \mathrm{Ma}$ (MSWD = 0.14; Figure 2 B). The high analytical error describes an isotopic disequilibrium caused by metamorphic (or metasomatic) activity.

terpretation because the proximity of the analytic point MR-1 with the intersection of the lines of CHUR and UR indicates little crustal contribution, being compatible with enriched mantle sources and/or juvenile crustal reservoir (e.g. DePaolo \& Wasserburg 1979; Arculus \& Powell 1986). However, samples LRDU-2, LRDU-3, AP-4 and AE-23 record isotopic disturbance due to high-grade regional metamorphism (Teixeira et al. 1996) or metasomatic alterations. Previous U-Pb work in rocks of CMLS by Goulart \& Carneiro 2010; Goulart et al. (2013a) yielded ages of $\approx 2713-2752 \mathrm{Ma}$ and pointed to the reworking of older crusts in the genesis of this Unit, recorded by 
$\mathrm{U}-\mathrm{Pb}$ zircon ages of $\approx 3374-2859 \mathrm{Ma}$ from inherited grains obtained in metarhyolite. This model, if correct, implies that the Sm-Nd $\mathrm{T}_{\mathrm{DM}}$ model ages of $\approx 3266-2860$ $\mathrm{Ma}$ represent an inherited isotope component of older crustal segments, formed during at least two main tectonothermal events recorded in the southern SFC, dated between 3220-3200 Ma and 2930$2900 \mathrm{Ma}$ (e.g. Teixeira et al. 1996, 1998; Lana et al. 2013). A third event occurred between 2780-2700 Ma (Machado \& Carneiro 1992, Carneiro 1992). This

\section{Acknowledgments}

We would like to thank Fapemig for the financial support to the project (MAC; CRA - RDP-00067-10) and

\section{References}

event consisted in the development of an active continental margin, generating tholeiitic to calc-alkaline magmatism besides the consumption and reworking of older crust, resulting in the stabilization of an extensive Archean sialic crust. The geochronological data of CMLS is consistent with this event, which at its end, gave place to widespread potassic magmatism of great magnitude (Romano et al. 2013; Lana et al. 2013). The Sm-Nd isochron age of $2736 \pm$ $300 \mathrm{Ma}$ obtained in this paper (Figure
2B) is interpreted as a good estimation for the time of crystallization of the CMLS and overlaps within error with these Neoarchean potassic magmatic event. The $\varepsilon \mathrm{Nd}_{(\mathrm{i})}=+0.4$ obtained in the isochron diagram indicates that original magmatism of CMLS was derived from depleted mantle sources and/or juvenile crustal reservoirs. This isotopic signature is consistent with environments of immature intra-oceanic arc, characterizing the evolution of the CMLS.
Capes for the doctoral scholarship (LEAG). Also we would like to thank Editor Evangelista H. J., Cristiano Lana and all anonymous reviewers for constructive comments.

ARCULUS, R. J., POWELL, R. Source component mixing in the regions of arc magma generation. J. Geophys. Res., 91(B6), p. 5913-5926, 1986.

CARNEIRO, M. A. O complexo metamórfico Bonfim Setentrional - Quadrilátero Ferrífero, Minas Gerais: litoestratigrafia e evolução geológica de um segmento continental do arqueano. São Paulo: Instituto de Geociências, Universidade de São Paulo, 1992. 233 p. (Tese de Doutorado).

CARNEIRO, M. A., TEIXEIRA, W., CARVALHO JR., I. M., PIMENTEL, M. M., OLIVEIRA, A. H.. Comportamento dos Sistemas Sm-Nd e Rb-Sr da Sequência Acamadada Máfico-Ultramáfica Ribeirão dos Motas (Arqueano), Cráton São Francisco Meridional: evidências de enriquecimento mantélico e fracionamento isotópico. Revista do Instituto de Geociências, USP, n. 2, v. 4, p.13-26, 2004.

CARNEIRO, M. A., ENDO I., NALINI JR. H.A., SALES, J. C. C., GOULART, L. E. A., SILVA, E. F., PEREIRA, A. A., TAVARES, T. D., JIAMELARO, F., CARNEIRO, J. M., MARIANO, L. C., PRADO, G. E. A., URBANO, E. P. C., SANTOS, C., MIGUEL, F. P. Nota explicativa da Folha Oliveira (Escala 1:100.000). Brasília: Convênio CPRM/UFOP (Programa Geologia do Brasil), 2007. $120 \mathrm{p}$.

DEPAOLO, D.J., WASSERBURG, G. J. Petrogenetic mixing models and Nd-Sr isotopic patterns. Geochimica et Cosmochimica Acta, v. 4, n. 43, p. 615-627, 1979.

DEPAOLO, D.J. Neodymium isotopes in the Colorado Front Range and crustalmantle evolution in the Proterozoic. Nature, 291, p. 193-197, 1981.

DEPAOLO, D.J. Neodymium isotope geochemistry - an introduction. SpringerVerlag, 1988. p. 178.

FAURE, G. Principles of Isotope Geology. John Williams \& Sons, 1988. 589 p.

GIOIA, S. M. C. I., PIMENTEL, M. M. The Sm-Nd isotopic method in the Geochronology Laboratory of the University of Brasilia. Anais da Academia Brasileira de Ciências, 72, p. 219-245, 2000.

GOULART, L. E. A., CARNEIRO, M. A. Episódios arqueanos de crescimento crustal na Porção Meridional do Cráton São Francisco: evidências U-Pb a partir da Sequência Acamadada Carmópolis de Minas (SACM), MG. In: CONGRESSO BRASILEIRO DE GEOLOGIA, 45. Anais... Belém: SBG, 2010.

GOULART, L. E. A., CARNEIRO, M. A., ENDO, I., SUITA., M. T. F. New evidence of Neoarchean crustal growth in southern São Francisco Craton: the Carmópolis de Minas Layered Suite, Minas Gerais, Brazil. Brazilian Journal of Geology, v. 43, n. 3, p. 445-459, 2013a.

GOULART, L. E. A., CARNEIRO, M. A., SUITA, M. T. F. Caracterização de um episódio de Arco-Magmatismo Neoarqueano no Cráton São Francisco Meridional: Suite Acamadada Carmópolis de Minas, MG, Brasil. 2013b (unpublished). 
LANA, C., ALKMIM, F., RICHARD ARMSTRONG, R., SCHOLZ, R., ROMANO, R., NALINI JR, H. A. The ancestry and magmatic evolution of Archaean TTG rocks of the Quadrilátero Ferrífero province, southeast Brazil. Precambrian Research, 231, p. 157-173, 2013.

LUDWIG K. G. Isoplot 3.0: a geochronological toolkit for microsoft excel. Berkeley: Geochronology Center Special Publication, 2000.p. 71.

MACHADO, N., CARNEIRO, M. A. U-Pb evidence of late Archean tectonothermal activity in the Southern São Francisco shield, Brazil. Canadian Journal of Earth Sciences, v. 29, p. 2341-2346, 1992.

MACHADO, N., SCHRANK, A. Geocronologia U-Pb do Maciço de Piumhí: resultados preliminares. In: SIMP. GEOL. MINAS GERAIS, 5. Anais... Belo Horizonte: SBG, 1989. p. 45-49.

MACHADO, N., NOCE, C. M., OLIVEIRA, O. A. B., LADEIRA, E. A. Evolução geológica do Quadrilátero Ferrífero no Arqueano e Proterozóico Inferior, com base em geocronologia U-Pb. In: SIMPÓSIO DE GEOLOGIA DE MINAS GERAIS, 5, SIMPÓSIO DE GEOLOGIA DE BRASILIA, 1. Anais... Belo Horizonte: SBG/ Núcleo MG, 1989. p. 1-5.

MORGAN, G. B., LONDON, D. Alteration of amphibolitic wallrocks around the Tanco rare-element pegmatite, Bernic Lake, Manitoba. American Mineralogist, 72, p. 1097-1121, 1987.

NOCE, C. M., MACHADO, N., TEIXEIRA, W. U/Pb Geochronology of gneisses and granitoids in the Quadrilátero Ferrífero (Southern São Francisco Craton): age constraints for Archean and Paleoproterozoic magmatism and metamorphism. Revista Brasileira de Geociências, v. 28, n. 1, p. 95-102, 1998.

PIMENTEL, M. M., FERREIRA FILHO, C. F. Idade Sm-Nd de komatiitos do greenstone belt Morro do Ferro, Fortaleza de Minas (MG). Revista Brasileira de Geociências, v. 32, n. 1, p. 147-148, 2002.

ROMANO, R., LANA, C., ALKMIM, F., F., STEVENS, G., S., ARMSTRONG, R. Stabilization of the southern portion of the São Francisco Craton, SE Brazil, through a long-lived period of potassic magmatism. Precambrian Research, 224, p. 143-159, 2013.

SATO K. Evolução crustal da plataforma sul-americana, com base na geoquímica isotópica Sm-Nd. São Paulo: Instituto de Geociências, Universidade de São Paulo, 1998. 297p. (Tese de Doutorado).

SATO, K., TASSINARI, C. C. G., KAWASHITA, K., PETRONILHO, L. O método geocronológico Sm-Nd no IG/USP e suas aplicações. Anais da Academia Brasileira de Ciências, Rio de Janeiro, v. 67, n. 3, p. 313-336, 1995.

STOREY, M., WOLFF, J. A., NORRY, M. J., MARRINER, G. F. Origin of hybrid lavas from Agua de Pau Volcano, São Miguel, Azores. In: SAUNDERS, A. D., NORRY, M. J. (ed.). Magmatism in the Ocean Basins, v. 42, p. 161-180, 1989. (Geological Society Special Publication of London).

TEIXEIRA, W., FONSECA, A. C., PADILHA, A. V., ZAPAROLlI, L. H., KAWASHITA, K., KHOURY, M. C. Esboço da evolução geotectônica da parte sul do Cráton do São Francisco: uma interpretação com base nos dados Rb/Sr, K/Ar, $\mathrm{Pb} / \mathrm{Pb}$ e traços de fissão. In: SIMPÓSIO DE GEOLOGIA DE MINAS GERAIS, 3. Anais... Belo Horizonte, SBG/Núcleo MG, 1985. p. 28-44.

TEIXEIRA, W., CARNEIRO, M. A., NOCE, C. M., MACHADO, N., SATO, K., TAYLOR, P. N. Pb, Sr and Nd isotope constraints on the Archean evolution of gneissic-granitoid complexes in the Southern São Francisco Craton. Precambrian Research, v. 78, p. 151-164, 1996.

TEIXEIRA, W., CORDANI, U. G., NUTMAN, A. P., SATO, K. Polyphase archean evolution in the Campo Belo Metamorphic Complex, Southern São Francisco Craton, Brazil: shrimp and U-Pb zircon evidence. Journal of South American Earth Science, v. 11, n. 3, p. 279-289, 1998.

TEIXEIRA, W., SABATÉ, P., BARBOSA, J., NOCE, C. M., CARNEIRO, M. A. Archean and Paleoproterozoic tectonic evolution of the São Francisco Craton. In: CORDANI, U. G., MILANI, E. J., THOMAZ FILHO, A., CAMPOS, D. A. (Ed.). Tectonic evolution of South America. Rio de Janeiro: SBG - 31 International Geological Congress, 2000. 855p., cap. IV. p. 101-137.

Artigo recebido em 30 de outubro de 2012. Aprovado em 08 de julho de 2013. 